\title{
Site Conditions for Jack Pine Seeding ${ }^{1}$
}

\author{
by Z. Chrosciewicz ${ }^{2}$
}

\begin{abstract}
There is a strong relationship between jack pine (Pinus banksiana Lamb.) regeneration and the combined site and seedbed conditions at the time of seeding. Both unfavorable and favorable seedbed characteristics, as well as available seed sources, are reviewed by groups of sites, and then optional uses of major seedbed and seeding treatments are discussed in terms of practical considerations. Site groups with regeneration potential ranging from high to low are also indicated.
\end{abstract}

Key words: Pinus banksiana, cutover areas, seedbeds, seed sources, mechanical scarification, controlled burning, seed-tree system, direct seeding, pine regeneration.

\section{Introduction}

Almost all jack pine (Pinus banksiana Lamb.) ${ }^{3}$ stands that are now harvested owe their existence to forest fires. This is because wild fires burning through the pine stands usually expose favorable mineral and organic seedbeds, reduce immediate plant competition, and trigger (by heating) seed dispersal from the otherwise serotinous cones on parent trees above the seedbeds. Abundant pine regeneration nearly always follows such fires, and only when the available seed sources are completely destroyed, as in burning young stands, for example, may the results be disappointing (Chrosciewicz 1988b). Generally, however, these favorable regeneration conditions are not met when the timber is harvested, and unless suitable remedial postcut treatments are carried out, the pine usually fails to regenerate in adequate numbers (Cayford et al. 1967). This paper reviews the basic seedbed requirements and then highlights some of the optional regeneration seeding methods that are more or less currently in use.

\section{Specific Conditions}

\section{The Forest Floor}

One of the important developments in our northern forests, including the jack pine stands, is the slow decomposition and consequent buildup of organic materials right on top of the mineral soil (Lutz and Chandler 1946, Weetman 1980). The process is maintained by the continuing growth of mosses and/or by the sustained additions of discarded dead foliage and other plant litter, including fractions of woody materials. This results in an organic mat that is thoroughly interwoven with plant roots, forming an integrated part of the forest floor.

\footnotetext{
'Paper presented at the Ontario Ministry of Natural Resources Symposium re. "Toward Prime Site Management", March 23-25, 1987. Thunder Bay, Ontario.

${ }^{2}$ Research Scientist, Northern Forestry Centre, Northwest Region, Forestry Canada, 5320-122 Street, Edmonton, Alberta T6H 3 S5.

'Species' nomenclature follows Scoggan (1957) for vascular plants and Crum et al. (1973) for mosses.
}

\section{Résumé}

Il existe une forte relation entre la régénération des pins gris (Pinus banksiana Lamb.) et les conditions de la station et du lit de germination au moment de l'ensemencement. L'auteur examine les caractéristiques défavorables et favorables du lit de germination ainsi que les sources disponibles de graines suivant les groupes de stations, puis il analyse l'utilisation-optionnelle des principaux traitements de préparation du lit de germination et d'ensemencement, du point de vue pratique. Des groupes de stations au potentiel de régénération variant de élevé à faiblé sont également indiqués.

Mots clés: Pinus banksiana, parterres de coupe, lits de germination, sources de graines, scarification mécanique, brûlage dirigé, mode de régénération par coupe rase avec semenciers. ensemencement direct, régénération des pins.
The accumulated materials are summarily called "raw humus", "mor humus", or simply "duff" if present on uplands, and "peat" if present on lowlands (Chrosciewicz 1978d, 1980). These materials vary in depth with stand age, stand density, stand composition, and site. Their profiles usually show downward increases in both decomposition and bulk density, starting with the unaltered moss and/or the loose, discarded dead foliage and other plant litter on the top, and ending with the fully decomposed, somewhat compacted true humus at the bottom. Most of the materials between these limits are in their fibrous, partly decomposed state, which in mors are permeated with fungal hyphae (Anon. 1978).

Among the main contributors to the buildup of these materials are feather mosses (mainly Pleurozium schreberi (Britt.) Mitt., but also Hylocomium splendens (Hedw.) B.S.G. and Ptilium crista-castrensis (Hedw.) De Not.) occasionally in association with reindeer mosses (Cladina spp.) on some of the poorer dry uplands, and in association with typical peat mosses (Sphagum spp.) on some of the poor wet lowlands (Chrosciewicz 1976, 1978d, 1980). However, dead foliage and other plant litter can be the main material on the forest floor if the stands have closed canopies and produce heavy leaf fall, which the feather-moss species in particular cannot tolerate (Place 1955).

\section{Unfavorable Seedbeds}

Poor seedbed conditions are created by both reindeer and feather mosses. The surface moss structures are generally loose and subject to rapid losses of moisture. When exposed to direct solar radiation as, for example, after harvest cutting, the feather moss in particular dies out, and so it further aggravates the predominately droughty seedbed conditions (Chrosciewicz 1978d, 1980, 1983b).

Poor seedbed conditions are also created by undisturbed raw humus (Eyre and LeBarron 1944, Baker 1950, Hawley and Smith 1954, Cayford et al. 1967). Consisting mostly of partially decomposed organic debris, which can be of considerable depth and which is always topped with an 
assortment of newly discarded bits and pieces of twigs, bark, foliage, and other plant litter, the raw humus is a formidable hindrance to jack pine regeneration. The materials form a loose meshwork of large noncapillary interstices that let rainfall through but then retard the upward movement of moisture as the surface strata dry out (Baker 1950). Moreover, the organic materials have low thermal conductivities, and when exposed to direct solar radiation they are subject to excessive surface temperatures (Cochran 1969). The losses of moisture are rapid under these conditions, and depending on depth, the entire raw humus may dry out in a matter of days after a drenching rain.

\section{Favorable Seedbeds}

Although some disturbance of the forest floor often occurs during logging operations, the resulting improvement of seedbeds is usually inadequate, and either mechanical scarification or controlled burning has to be used to rectify the situation. Under the weather and site conditions that prevail on our northern cutovers, the favorable jack pine seedbeds include mineral soil exposed by scarification or burning (Eyre and LeBarron 1944, Ahlgren 1970, Chrosciewicz 1959, 1960b, 1967, 1970, 1974, Cayford et al. 1967), lower raw humus strata exposed by scarification or burning (Cayford et al. 1967, Chrosciewicz 1967, 1970, 1974, 1978a, 1988b), and lower peat strata exposed preferably by burning (Chrosciewicz 1976). One exception to this is the seemingly always moist Sphagnum which by itself can be a favorable seedbed medium even when undisturbed, especially for black spruce (Picea mariana (Mill.) B.S.P.) (Heinselman 1957, Losee 1961, Chrosciewicz 1976).

When exposed, the mineral soil is universally recognized as the best medium for jack pine regeneration (Eyre and LeBarron 1944, Baker 1950, Haig 1959, Chrosciewicz 1959, 1960b, 1967, 1970, 1974, Jarvis 1966, Cayford et al. 1967, Arnott 1973, Brown 1973). It maintains the upward movement of moisture by capillary action, and the nature of its particles is well suited to provide close contacts between the seed and the surface films of that moisture (Baker 1950). As a source of moisture, therefore, the mineral soil is considered much more stable than most organic seedbeds (Smith 1962), which generally lack these important attributes (Baker 1950).

The mineral soil also has a good thermal conductivity (Baker 1950), enabling it to transmit heat downward fast enough to maintain correspondingly lower surface temperatures (Cochran 1969). The moisture contained in the mineral soil also helps to mitigate the surface temperatures both through the cooling effect of evaporation and by increasing thermal conductivity (Geiger 1957). Nevertheless, to mitigate the effects of drought even on the best mineral seedbeds, some degree of shade is essential for good germination and early survival of seeded jack pine. Once the seedlings are firmly established with leaders above the surrounding vegetation, they grow best in full sunlight (Chrosciewicz 1960a).

This is as far as generalities go. The water-holding capacity of mineral soil normally increases with the increasing content of silt plus clay, and this has a positive effect on the establishment of seeded pine, even where the exposed material is just silty sand (Chrosciewicz 1970). In contrast, a nearly pure upland outwash sand may be at times so dry when exposed that the seeded pine completely fails to regenerate (Chrosciewicz 1983a). However, a texturally indentical outwash sand, but in a lowland situation and having a midsummer water table of at least $0.9 \mathrm{~m}$ below the surface, is well suited as a regeneration medium for the seeded pine, even when it is only partially exposed. The favorable seedbed conditions in the latter example are attributed to the periodic presence of a high water table that supplies the soil profile with much of its moisture in addition to the amounts of rainfall received (Chrosciewicz 1983a).

When the generally more compacted lower raw humus strata become exposed as a result of scarification or burning, favorable seedbeds are also created. In fact, on productive upland sites with a relatively shallow raw humus, deep mineral profiles, and Hills' (1955) soil moisture regimes $\leq 3$, the best seedbed conditions are produced where exposed mineral soil and thin residual humus alternate and both have uniform areal distribution (Chrosciewicz 1970, 1974, $1980,1983 b)$. Deeper raw humus materials and lowland peats over deep mineral profiles with effective high water tables and Hills' (1955) soil moisture regimes $\geq 4$, become favorable seedbeds almost as soon as the generally loose surface moss and litter materials are burned off or perhaps mechanically removed if at all practical (Chrosciewicz 1976, 1980, 1983a).

In all cases, the quality of seedbeds normally improves with the depth reduction of organic forest-floor materials. This, however, does not mean that complete removal or destruction of such materials is required to produce optimum seedbeds. On the contrary, large quantities of insoluble nutrient compounds are stored in those materials, and although some disturbance is usually needed to make the nutrients more readily available to the plants, a complete removal or destruction of such materials either by scarification or by burning is extremely wasteful and must be avoided. This is particularly critical in dry upland situations where the mineral soil is nutritionally poor outwash sand or gravel, drains very rapidly, has a very low water-holding capacity, and frost-heaves when exposed. A complete removal or destruction of the organic forest-floor materials can also be harmful if the mineral soil is clay or contains much clay, because then on drying its surface structure breaks down into extremely compacted fractional aggregates that interfere with normal plant rooting. The object of most silvicultural uses of scarification and burning is therefore not the total removal or destruction of all organic forest-floor materials present, but rather their reduction to a degree sufficient for prompt reestablishment of seeded pine whenever required (Chrosciewicz 1978d).

Perhaps the most important factors affecting the moisture content of seedbeds, and consequently the ultimate success or failure of seeding, are the amount and distribution of rainfall (Smith 1964). Some seedbeds that are considered favorable under normal rainfall conditions may not be so during periods of drought, and some of those that are usually unfavorable may manifest favorable characteristics in response to prolonged periods of wet weather. In fact, both the deficit and low frequency of rainfall (Chrosciewicz 1983a) as well as the surplus and high frequency of rainfall (Chrosciewicz 1983b) can have profound, though opposite effects on the quality of seedbeds rated in terms of pine regeneration. Unfortunately, abnormal patterns of rainfall are seldom predictable and so are some of the results of jack pine seeding. 


\section{Available Seed Sources}

Jack pine is reputed to be a prolific producer of seeds. It is not unusual for a well-stocked, mature stand on a good site to yield about $14.5-15.1 \mathrm{~kg}$ of seeds/ha (Eyre and LeBarron 1944). At that age, the cones containing these seeds are usually situated high in the crowns. Most of them are serotinous and are just waiting for the heat of the next fire to initiate their opening and subsequent seed dispersal over the fire-improved seedbeds right below the parent trees. The potential for a dependable stand rejuvenation therefore always exists under such conditions. However, when the timber is harvested through clear-cutting, the entire mass of conebearing branches is brought down to the ground, where in situ they are subject to cone opening by the heat of solar radiation. In this case, the seeds are released over the unimproved original seedbeds and so, under normal weather conditions, they in time become completely wasted. Only when the branches with cones are lopped and scattered at some spacing over an exposed mineral soil nearby prior to cone opening, can the subsequent release of seeds from the cones result in pine regeneration (Cayford 1958, Chrosciewicz 1960b, 1971).

Whether in the crowns of parent trees or on branches near the ground in logging slash, jack pine cones require a temperature of at least $50^{\circ} \mathrm{C}$ for the bonds between their scales to melt and thus start their opening through the forces of desiccation (Cameron 1953). In both locations, the cones are valuable sources of seeds and they should be used as much as possible in our treatment to regenerate the pine after cutting. At this point one must remember that the cones in slash hold their seeds in ever-diminishing numbers for one or perhaps two years, and that their usefulness is practically nil thereafter (Chrosciewicz 1960b). Moreover, one should also know that slash burning alone cannot be regarded as a dependable means of releasing the seeds from cones in that slash, because the fire either completely destroys the seeds or, if some survive, it drastically reduces their viability from the normal value of about $80 \%$ down to around $5 \%$ (Chrosciewicz 1959).

To preserve the source of seeds in jack pine slash, wholetree logging with subsequent delimbing of crown elements at some central location, or at a roadside, should be discouraged. This not only deprives the clearcut site of a cost-free, readily available seed source for the short-order regeneration treatment, but it also strips the site of a valuable postcut addition of nutrients which should be rightfully returned back to the soil. On nutrient-poor sites, in particular, the latter may lead to the establishment of stands of low productivity (Hendrickson et al. 1987). It is then quite possible that the whole-tree logging can be more efficient and hence more economical than other methods of timber extraction, but eventually someone else will have to bear the resulting extra costs of regeneration and perhaps of site amelioration. In short, the logging operation and its consequences should be always compatible with the overall plan for the postcut pine regeneration and its projected development.

\section{Optional Treatments}

\section{Mechanical Scarification and Slash Redistribution}

Drag scarification of the forest floor with simultaneous redistribution of the cone-bearing slash is one of the most dependable methods of regenerating the pine after clearcutting. This method takes the full advantage of the ample seed source that is locally available, and if it is used during the summer months after logging, or as soon as the slash becomes sufficiently brittle, good scarification and slash redistribution is achieved.

The object of this type of operation is to produce up to $100 \%$ of disturbance with well-distributed patches of exposed mineral soil totalling at least $40-50 \%$ in area and having a light cover of cone-bearing branches over them. Reasons for failure of this treatment may include poorly executed scarification and/or insufficient seed availability because of excessively delayed scarification. A shortage of available seeds can also result from whole-tree logging when most of the slash is removed from the site. It is otherwise not unusual to have the clear-cut sites $90-93 \%$ stocked $^{4}$ to jack pine 5 years after the treatments (Ball 1975).

The drag equipment usually consists of ship anchor chains with double spikes welded into the links. Five 6-m chains are often attached to a 4-m drawbar and pulled either by a wheeled skidder as on dry uplands where less pull is required or by a tracked machine elsewhere where more pull is needed. The recommended weights of drag chains and the size of machinery vary directly with the relative weight of slash and the mean depth of raw humus (Anon. Undated).

\section{Controlled Burning and Seed-Tree System}

Slash burning in conjunction with a seed-tree system is perhaps the most natural method of regenerating jack pine after cutting. It also takes advantage of the locally available seed source, but in this case seed trees must be marked and left standing while all other timber is harvested. Burning of logging slash here improves the seedbeds and the heat so generated is sufficient to initiate cone opening on the seed trees. The dispersal of seeds by the trees is at first intensive; then later it becomes more gradual and usually lasts for up to 3 years after burning. This gives the pine an ample opportunity to regenerate under a variety of weather conditions, including the favorable ones for its establishment.

Generally, there are very few recorded instances of successful jack pine regeneration by this method. Burning under an open stand (Chrosciewicz 1959) as well as two other examples of burning under designated seed trees (Ahlgren 1970; Chrosciewicz 1988b) certainly belong to this category, with the pine stocking of 60,83 , and $90 \% 4$ years after burning, respectively. Extensive operational trials with the burning and seed-tree systems are now required to determine their economic feasibility at that level of implementation (Chrosciewicz 1988b).

Means of selecting the proper conditions for burning the desired amounts of raw humus are already available and require only local adaptation (Chrosciewicz 1978a, 1978b, 1978c). About 20 seed trees/ha should provide satisfactory postburn seeding (Chrosciewicz 1988b).

\section{Mechanical Scarification and Direct Seeding}

Old cutovers, old burns, and other poorly regenerated areas are often suitable for scarification and direct seeding. In

\footnotetext{
${ }^{4}$ The stocking values as quoted in this paper are based on sample quadrants of variable size, $4.05 \mathrm{~m}^{2}$ for old surveys and $4.00 \mathrm{~m}^{2}$ for recent surveys.
} 
practice, mechanical scarification includes all degrees of mineral soil exposure, from very little to extreme. The exposure may be at random with considerable intermixing of organic materials, in parallel strips or furrows, or in uniformly spaced scalps. Among the equipment currently in use are: (a) diverse bulldozer blades, shark-finned drums, and anchor chains for more or less strip and random scarification; (b) plows, rippers, and disk trenchers for scarification in furrows; and (c) various spot cultivars for scarification in scalps (Cayford et al. 1967, Hellum 1973, Rudolf 1973, Waldron 1973, Norman 1978, Orynik 1985, Peterson 1985).

Direct seeding may involve spot seeding with special cultivators which automatically release a few seeds on each scarified scalp. It may be done as row seeding with some other devises that space the seeds evenly along the plowed furrows. Otherwise, Cyclone seeders may be used where postscarification broadcast seeding is the objective. This can be done by covering the ground on foot, by snowmobile, or by helicopter, although a fixed-wing aircraft and a Brohm seeder is the better combination (Chrosciewicz 1980).

Because the amount of seed sown and the season of seeding vary considerably from operation to operation, the results are extremely erratic (Hellum 1973, Rudolf 1973, Waldron 1973). However, the pine stocking is directly related to the proportion of favorable seedbeds that is available (Riley 1980). A well-distributed mineral soil exposure of $15-25 \%$ and an aerial seeding of pine at the rate of 50000 viable seeds/ha are usually required to ensure consistently at least $60 \%$ stocking 3 years after the treatments. As the amount of seeds sown increases above 50000 seeds/ha, the stocking does not increase significantly (Riley 1980, Smith 1984). Whether on the ground or from the air, all broadcast seeding should be done in early spring either over a fresh snow or before the snow leaves the ground (Brown 1973, Hellum 1973, Smith 1984). If the Bräcke is used as a spot scarifier and seeder, the pine stocking of $60 \%$ or better can be obtained when the operation takes place during the (presumable snowfree) spring period and when the seeding rate is 15 viable seeds per scarified scalp (Clark 1984).

\section{Controlled Burning and Direct Seeding}

Whether the burning is conducted with or without presence of seed trees similar weather and fuel conditions are required for the desired improvement of seedbeds. The moisture contents of the forest-floor organic materials control the depth of burn into the raw humus as well as the consequent degree of mineral soil exposure. There are several available regressions between the Duff Moisture Codes (DMCs) ${ }^{5}$ representing these moisture contents and the results of burning for different standardized mean preburn humus depths which in turn represent the different sites or groups of sites (Chrosciewicz 1978a, 1978b). Specific guidelines on how to conduct the burns are also available (Chrosciewicz 1978c). All of this information can be used to select the proper DMC and other conditions for the use of burning that would best match the local situation. Summer burning as compared with spring burning is preferable because it produces better results in terms of seedbed improvement (Chrosciewicz 1959, 1967, 1974). The cured logging slash

${ }^{5}$ A component of the Canadian Forest Fire Weather Index System (Anon. 1984). and other dead plant materials are important, mainly in sustaining fire ignition and its spread.

Here again the amount of seed sown, $0.35-2.24 \mathrm{~kg} / \mathrm{ha}$ (viability $50-89 \%$ ), varies substantially from operation to operation, often to test the effect of different fire-produced seedbeds by diverse physiographic sites and/or in relation to both constant-single and constant-double seeding rates. These are applied mostly in the spring, but with some replications also in the fall (Chrosciewicz 1959, 1970, 1983a, 1983b, 1987, 1988a). A Cyclone seeder is used in most such operations, although other broadcasting methods on the ground and from air are also being tried.

On the whole, the resulting jack pine regeneration is significantly better after spring seeding than after fall seeding (Chrosciewicz 1987), and out of 80 spring seeding tests, 12 completely failed because of abnormally droughty weather and poor soil conditions (Chrosciewicz 1983a), 38 produced $16-60 \%$ stocking, and the remaining 30 produced $61-99 \%$ stocking, 3-9 growing seasons after the treatments (Chrosciewicz 1959, 1970, 1983a, 1983b, 1987, 1988a). In one instance, a postburn scarification and aerial application of 50000 viable seeds/ha resulted in $80 \%$ pine stocking (Smith 1984).

After so much testing, there is a general feeling and recognition that the burning and seeding treatments should be primarily used on those nonreproducing lowland problem sites where mechanical scarification is either too expensive, too difficult, or simply too messy to even be considered. There is so far not even one instance of failure on such sites, and certainly there the burning and seeding treatments are capable of producing well-stocked and fast-growing pine stands. A permanent water table at 0.6-1.5 m below the surface is the common and necessary feature of these sites. Sandy outwash plains, river terraces, and similar other lowland formations regardless of mineral texture belong to this category. The fire-induced exposure of mineral soil on these sites is usually minimal, and the pine germinates and develops well on partially burned humus.

Next in line of priorities are the richer upland sites with silty and loamy sands, sandy loams, loams, glacial tills, etc., within their mineral soil profiles. The total fire-induced exposure of mineral soil on these sites should be about $50 \%$ and well alternating in its patch-like distribution with the residual, partially burned humus. The risks of failure and the chances of a wide variation of results in pine regeneration are much greater here than on the lowlands.

The last category of sites with deep mineral soil profiles under consideration consists of poor-quality sandy uplands, particularly in areas subject to periodic droughts. Neither burning nor seeding treatments, whether singly or in combination, should be conducted on these sites because the possibilities of successful pine regeneration here are extremely small. On sites such as these, one has no other recourse than to apply the Triple-P treatments, which may conceivably be: plow, plant, and ... pray.

\section{Concluding Comments}

Indications are that with the proper selection of treatable sites and the right treatment prescriptions best fitting the local conditions, both the risks of failure and the costs incurred in regenerating the pine can be substantially minimized. However, there are on occasion problems related to density 
and spacing in at least some of the seeded strands. Understocking seems to be the most frequent problem, although when seeding and all other conditions are just right, overcrowding can occur. Density adjustments, either by fillingin the regeneration gaps or by thinning the overcrowding when it occurs, may be required in seeded stands. Some of this should be controlled by adjusting the intensity of treatments associated with seeding, and the remaining costs of stand tending, if needed, should then be covered by the accrued savings in the costs of seeding versus the costs of planting. As for the problem of seedling clumps on the scarified and seeded scalps when spot cultivators are used, the naturally differing assertion of dominance by the pine is the likely solution. In the final analysis, the seeded stands may prove to have better rooting, better form, and better growth rates than some of their planted counterparts. This is at least evident whenever comparisons are made between the natural and the planted pine regeneration (Segaran et al. 1978).

\section{References}

Ahlgren, C.E. 1970. Some effects of prescribed burning on jack pine regeneration in northern Minnesota. Univ. Minnesota, Agric. Exp. Stn., St. Paul. Minn. Misc. Rep. No. 94, For. Ser. 5.

Anon. 1978. The Canadian system of soil classification. Can. Dep. Agric., Res. Branch, Can. Soil Surv. Comm., Ottawa, Ont. Publ. No. 1646.

Anon. 1984. Tables for the Canadian Forest Fire Weather Index System. Environ. Can., Can. For. Serv., Hull, Que. For. Tech. Rep. No. 25 (4th ed.).

Anon. Undated. Drag scarification in British Columbia. B.C. Min. For., Victoria, B.C. ISBN 0-7719-8143-0.

Arnott, J.T. 1973. Germination and seedling establishment. Pages 55-66 in J.H. Cayford (editor). Direct seeding symposium. Proceedings. Can. Dep. Environ., Can. For. Serv., Ottawa, Ont. Publ. No. 1339.

Baker, F.S. 1950. Principles of Silviculture. McGraw-Hill Co., New York, N.Y.

Ball, W.J. 1975. An appraisal of natural regeneration on scarified jack pine cutovers, Saskatchewan. Environ. Can., Can. For. Serv., North For. Res. Cent., Edmonton, Alta. Inf. Rep. NOR-X-136.

Brown, G. 1973. Direct seeding in Ontario. Pages 119-124 in J.H. Cayford (editor). Direct seeding symposium. Proceedings. Can. Dep. Environ., Can. For. Serv., Ottawa, Ont. Publ. No. 1339.

Cameron, H. 1953. Melting point of the bonding material in lodgepole pine and jack pine cones. Can. Dep. Resour. Dev., For Branch., Div. For. Res., Ottawa, Ont. Silv. Leaf. No. 86.

Cayford, J.H. 1958. Scarifying for jack pine regeneration in Manitoba. Can. Dep. North. Aff. Natl. Resour., For. Branch, For. Res. Div., Ottawa, Ont. Tech. Note No. 66.

Cayford, J.H., Z. Chrosciewicz and H.P. Sims. 1967. A review of silvicultural research in jack pine. Can. Dep. For. Rural Dev., For. Branch, Ottawa, Ont. Publ. No. 1173.

Chrosciewicz, Z. 1959. Controlled burning experiments on jack pine sites. Can. Dep. North. Aff. Natl. Resour., For. Branch, For. Res. Div., Ottawa, Ont. Tech. Note. No. 72

Chrosciewicz, Z. 1960a. A spot seeding trial with jack pine. Can. Dep. North. Aff. Natl. Resour., For. Branch, For. Res. Div., Ottawa, Ont. Mimeo 60-1.

Chrosciewicz, Z. 1960b. Jack pine regeneration after scattering slash on exposed mineral soil. Pulp. Pap. Mag. Can. 61: 164-166.

Chrosciewicz, Z. 1967. Experimental burning for humus disposal on clearcut jack pine sites in central Ontario. Can. Dep. For. Rural Dev., For. Branch, Ottawa, Ont. Publ. No. 1181.

Chrosciewicz, Z. 1970. Regeneration of jack pine by burning and seeding treatments on clear-cut sites in central Ontario. Can. Dep. Fish. For., Can. For. Serv., For. Res. Lab., Ont. Reg., Sault Ste. Marie, Ont. Inf. Rep. O-X-138.

Chrosciewicz, Z. 1971. The growth response of young jack pine to moderate and extreme stand densities. Bi-Mon. Res. Notes 27: 6.

Chrosciewicz, Z. 1974. Evaluation of fire-produced seedbeds for jack pine regeneration in central Ontario. Can. J. For. Res. 4: 455-457.

Chrosciewicz, Z. 1976. Burning for black spruce regeneration on a lowland cutover site in southeastern Manitoba. Can. J. For. Res. 6: 179-186.
Chrosciewicz, Z. 1978a. Slash and duff reduction by burning on clear-cut jack pine sites in southeastern Manitoba. Fish. Environ. Can., Can. For. Serv., North. For. Res. Cent., Edmonton, Alta. Inf. Rep. NOR-X-199.

Chrosciewicz, Z. 1978b. Slash and duff reduction by burning on clear-cut jack pine sites in central Saskatchewan. Fish. Environ. Can., Can. For. Serv., North. For. Res. Cent., Edmonton, Alta. Inf. Rep. NOR-X-200.

Chrosciewicz, Z. 1978c. Large-scale operational burns for slash disposal and conifer reproduction in central Saskatchewan. Fish. Environ. Can., Can. For. Serv., North. For. Res. Cent., Edmonton, Alta. Inf. Rep. NOR-X-201.

Chrosciewicz, Z. 1978d. Silvicultural uses of fire in mid-western Canada Pages 37-46 in D.E. Dubé (compiler). Fire ecology in resource management. Workshop proceedings. Environ. Can., Can. For Serv., North. For. Res. Cent., Edmonton, Alta. Inf. Rep. NOR-X-210.

Chrosciewicz, Z. 1980. Some practical methods of securing adequate postcut forest reproduction in Canada. Pages 49-52 in M. Murray and R.M. Van Weldhuizen (editors). Forest regeneration at high latitudes. The proceedings of an international workshop. USDA For. Serv., Pac. Northwest For. Range Exp. Stn., Portland, Ore. Gen. Tech. Rep. PNW-107.

Chrosciewicz, Z. 1983a. Jack pine regeneration following postcut burning and seeding in southeastern Manitoba. Environ. Can., Can. For. Serv., North. For. Res. Cent., Edmonton, Alta. Inf. Rep. NOR-X-252

Chrosciewicz, Z. 1983b. Jack pine regeneration following postcut burning and seeding in central Saskatchewan. Environ. Can., Can. For. Serv. North. For. Res. Cent., Edmonton, Alta. Inf. Rep. NOR-X-253.

Chrosciewicz, Z. 1987. Evaluation of postburn seeding of jack pine in central Saskatchewan. Can. For. Serv., North. For. Cent., Edmonton, Alta. For. Manage. Note No. 41

Chrosciewicz, Z. 1988a. Forest regeneration on burned, planted, and seeded clear-cuts in central Saskatchewan. Can. For. Serv., North. For. Cent., Edmonton, Alta. Inf. Rep. NOR-X-293.

Chrosciewicz, Z. 1988b. Jack pine regeneration following postcut burning under seed trees in central Saskatchewan. For. Chron. 64: 315-319.

Clark, A. 1984. Ground seeding requirements for jack pine regeneration. Pages 87-92 in C.R. Smith and G. Brown (cochairmen). Jack pine symposium. Proceedings. Can. Dep. Environ., Can. For. Serv., Great Lakes For. Res. Cent., Sault Ste. Marie, Ont. COJFRC Symp. Proc. O-P-12.

Cochran, P.H. 1969. Thermal properties and surface temperatures of seedbeds. USDA For. Serv., Pac. Northwest For. Range Exp. Stn. Portland, Ore. Misc. Publ. No. 12.

Crum, H.A., W.C. Steere and L.E. Anderson. 1973. A new list of mosses of North America north of Mexico. Bryologist 76: 85-130.

Eyre, F.H. and R.K. LeBarron. 1944. Management of jack pine stands in the Lake States. USDA. Washington. D.C. Tech. Bull No. 863.

Geiger, R. 1957. The Climate Near the Ground. Harvard Univ. Press, Cambridge, Mass.

Haig, R.A. 1959. Result of an experimental seeding in 1920 of white spruce and jack pine in western Manitoba. For. Chron. 35: 7-12.

Hawley, R.C. and D.M. Smith. 1954. The Practice of Silviculture. John Wiley and Sons, Inc., New York, N.Y.

Heinselman, M.L. 1957. Living Sphagnum found most favorable seedbed for swamp black spruce in Minnesota study. USDA For. Serv., Lake States For. Exp. Stn., St. Paul, Minn. Tech. Note 504

Hellum, A.K. 1973. Direct seeding in western Canada. Pages 103-111 in J.H. Cayford (editor). Direct seeding symposium. Proceedings. Can. Dep. Environ., Can. For. Serv., Ottawa, Ont. Publ. No. 1339.

Hendrickson, O.Q., D.M. Burgess and L. Chatarpaul. 1987. Biomass and nutrients in Great Lakes - St. Lawrence forest species: implications for whole-tree and conventional harvest. Can. J. For. Res. 17: 210-218.

Hills, G.A. 1955. Field methods for investigating site. Ont. Dep. Lands For., Res. Div., Maple, Ont. Site Res. Man. No. 4.

Jarvis, J.M. 1966. Seeding white spruce, black spruce and jack pine on burned seedbeds in Manitoba. Can. Dep. For., For. Res. Branch. Ottawa, Ont. Publ. No. 1166.

Losee, S.T.B. 1961. Results of group cutting for black spruce regeneration at the Abitibi Woodlands Laboratory. Can. Pulp Pap. Assoc. Woodl. Sect., Montreal, Que. Index No. 2086 (F-2).

Lutz, H.J. and R.F. Chandler. 1946. Forest Soils. John Wiley and Sons. Inc., New York, N.Y. 
Norman, C.M. 1978. Ripper scarification: a silvicultural technique developed in northwestern Alberta. For. Chron. 54: 15-19.

Orynik, R.J. 1985. Mechanized silviculture at Prince Albert Pulpwood. Pages 37-39 in J.R. Gorman (compiler). Proceedings of the 1984 mechanized silviculture workshop. Can. For. Serv.. North. For. Res. Cent.. Edmonton, Alta. Inf. Rep. NOR-X-272.

Peterson, G. 1985. Silvicultural equipment used in Manitoba. Pages 17-20 in J.R. Gorman (compiler). Proceedings of the 1984 mechanized silviculture workshop. Can. For. Serv., North. For. Res. Cent., Edmonton. Alta. Inf. Rep. NOR-X-272.

Place, I.C.M. 1955. The influence of seedbed conditions on the regeneration of spruce and balsam fir. Can. Dep. North. Aff. Natl. Resour., For. Branch, For. Res. Div., Ottawa, Ont. Bull. No. 117.

Riley, L.F. 1980. The effect of seeding rate and seedbed availability on jack pine stocking and density in northeastern Ontario. Can. Dep. Environ., Can. For. Serv.. Sault Ste. Marie, Ont. Inf. Rep. O-X-318.

Rudolph, J.T. 1973. Direct seeding versus other regeneration techniques: Silvicultural aspects. Pages 29-34 in J.H. Cayford (editor). Direct seeding symposium. Proceedings. Can. Dep. Environ., Can. For. Serv., Ottawa, Ont. Publ. No. 1339.

Scoggan, H.J. 1957. Flora of Manitoba. Can. Dep. North. Aff. Natl. Resour., Natl. Mus. Can., Ottawa, Ont. Bull. No. 140.

Segaran, S., J.C. Dojack and R.K. Rathwell. 1978. Assessment of root deformities of jack pine (Pinus banksiana Lamb.) planted in southeastern Manitoba. Pages 197-200 in E. Van Eerden and J.M. Kinghorn (editors). Proceedings of the root form of planted trees symposium. B.C. Min. For./Can. For. Serv., Victoria, B.C. Joint Rep. No. 8.

Smith, D.M. 1962. The Practice of Silviculture. John Wiley and Sons, Inc.. New York, N.Y.

Smith, D.M. 1964. Summary and discussion of symposium on direct seeding. Pages 115-119 in H.G. Abbot (editor). Direct seeding in the northeast. Proceedings. College Agric., Univ. Mass., Amherst. Mass.

Smith, B.W. 1984. Aerial seeding requirements for jack pine regeneration. Pages 78-86 in C.R. Smith and G.B. Brown (cochairmen). Jack pine symposium. Proceedings. Can. Dep. Environ., Can. For. Serv.. Great Lakes For. Res. Cent., Sault Ste. Marie, Ont. COJFRC Symp. Proc. O-P-12.

Waldron, R.M. 1973. Direct seeding in Canada 1900-1972. Pages 11-27 in J.H. Cayford (editor). Direct seeding symposium. Proceedings. Can. Dep. Environ., Can. For. Serv., Ottawa, Ont. Publ. No. 1339.

Weetman, G.F. 1980. The importance of raw humus accumulation in boreal forest management. Pages 7-9 in M. Murray and R.M. Van Veldhuizen (editors). Forest regeneration at high latitudes. The proceedings of an international workshop. USDA For. Serv., Pac. Northwest For. Range Exp. Stn., Portland, Ore. Gen. Tech. Rep. PNW-107.

The University of New Brunswick is seeking applications for the position of

\title{
Dean of the Faculty of Forestry
}

to succeed the incumbent effective July 1, 1991.

The faculty of Forestry is the only English Language professional Forestry School in Atlantic Canada and has a long and distinguished history in education, research and service. The Faculty has strong undergraduate, graduate and research programs. It offers the Bachelor's and Master's degrees in Forestry and Forest Engineering and the Ph.D. in Forestry.

The Faculty is a participant in the Hugh John Flemming Forestry Complex located adjacent to the Fredericton Campus, a centre of excellence for forest-related research and development, and has strong ties with forestry agencies in both government and industry. The Faculty also operates a continuing education program.

The Dean should have outstanding academic, research and administrative qualifications and be capable of providing strong leadership in forestry education within a dynamic local and national forestry environment.

Enquiries, nominations and applications should be addressed to:

\author{
Dr. R.E. Burridge \\ Vice-President (Academic) \\ Chairman, Search Committee for Dean of Forestry \\ The University of New Brunswick \\ P.O. Box 4400 \\ Fredericton, New Brunswick \\ Canada E3B 5A3
}

by January 15, 1991. Applications should include a curriculum vitae and the names of three referees. It is intended to make an appointment effective July 1, 1991.

In accordance with Canadian immigration requirements, this advertisement is directed to Canadian citizens and those holding Landed Immigrant status in Canada.

THE UNIVERSITY OF NEW BRUNSWICK IS COMMITTED TO THE PRINCIPLE OF EMPLOYMENT EQUITY 